\title{
Carcass and Meat Quality Characteristics of Omani Sheep Fed Diets Based on Raw or Processed Mesquite (Prosopis Juliflora) Pods
}

\author{
Al-Khalasi $\mathrm{S}^{* 1}$ and Mahgoub $\mathrm{O}^{2}$ \\ ${ }^{1}$ Ministry of Agriculture and Fisheries, Department of Animal Wealth, Oman \\ ${ }^{2}$ Department of Animal and Veterinary Sciences, College of Agricultural and Marine Sciences, Sultan Qaboos University, \\ Oman
}

${ }^{*}$ Corresponding author: Al-Khalasi S, Ministry of Agriculture and Fisheries, Department of Animal wealth P.O Box 60, Nizwa 611, Oman, Tel: 0096899479224, E-mail: saidalkhalasi@gmail.com

Citation: Al-Khalasi S, Mahgoub O (2018) Carcass and Meat Quality Characteristics of Omani Sheep Fed Diets Based on Raw or Processed Mesquite (Prosopis Juliflora) Pods. J Vet Sci Ani Husb 6(3): 301.

doi: 10.15744/2348-9790.6.301

Received Date: February 20, 2018 Accepted Date: August 21, 2018 Published Date: August 23, 2018

\begin{abstract}
Inclusion of soaked or roasted Mesquite pods at high level in concentrate diets for sheep to improve feed intake and reduce production cost has not been studied. The novelty of this study was to evaluate the effect of incorporating soaked or roasted Mesquite pods at $50 \%$ level in formulated concentrates on carcass and meat quality of Omani sheep. The Mesquite-pod-based diets were formulated and pelleted from $500 \mathrm{~g} / \mathrm{kg}$ ground Mesquite pods, $240 \mathrm{~g} / \mathrm{kg}$ wheat bran, $200 \mathrm{~g} / \mathrm{kg}$ barley grain, $50 \mathrm{~g} / \mathrm{kg}$ local dried sardines and $10 \mathrm{~g} / \mathrm{kg}$ of salt. Twenty four 10 months-old intact Omani male lambs with average body weight of $27.3 \mathrm{~kg}( \pm 0.5 \mathrm{~kg})$ were used in a feeding trial for 84 days. They were allocated to four diet combination groups; commercial concentrate (CC); raw Mesquite pods based concentrate (RMPC); roasted Mesquite pods based concentrate (ROMPC) and soaked Mesquite pods based concentrate (SMPC) group. The sheep fed CC had higher $(\mathrm{P}<0.05)$ slaughter weight, carcass weight and empty body weight $(\mathrm{EBW})$ and full digestive tract content compared to both RMPC and SMPC groups but not with those fed ROMPC. There were no significant treatment differences in proportion of hot and cold carcass weight, dressing-out percentage (DOP) and cold shrinkage percentage. There were also no differences in proportions of all non-carcass components in EBW. The carcass characteristics and meat quality indicated no significant differences with an exception that sheep fed with ROMPC and CC had increased carcass weights, and ROMPC fed animals had carcass with higher expressed juice. The present study demonstrated the potential of using Mesquite pods in formulated ration at level of $500 \mathrm{~g} / \mathrm{kg}$ for growing lambs without adverse effects on carcass characteristics or meat quality.
\end{abstract}

Keywords: Mesquite; Sheep; Meat Quality

\section{Introduction}

Sheep are important meat-producing animals worldwide, including Oman. Growth and development are the bases for meat production whereas distribution of carcass tissue is significant in determining carcass quality. Besides the dressed carcass, many parts of the animal body are also consumed (e.g. head, feet, liver, heart, stomach and intestines) or sold (e.g. skin and wool). Omani native sheep have good potential for meat production, reflected by their high growth rates and good carcass characteristics, when raised under optimum management and nutritional conditions [1].

Availability of cheap animal feed of good nutritive value is essential for profitable animal production. There are some readily available livestock feeds in the natural range grazing and browsing land as well as agricultural by-products in Oman. However, these types of feeds are usually high in fibre and low in quality and need to be supplemented with protein, energy, minerals and vitamin sources to improve their nutritive value for livestock feeding.

Mesquite (Prosopis juliflora) is a drought resistant, evergreen, spiny tree grows in semi-arid and arid tracts of tropical and subtropical regions of the world.

Obeidat et al. (2008) [2] studied the effects of inclusion of Mesquite pods at levels of 100 and $200 \mathrm{~g} / \mathrm{kg}$ in Awassi lambs finishing diets on growth, digestibility, and carcass and meat characteristics. They found no differences between experimental groups in dressing percentage, hot and cold carcass weights, non-carcass components, carcass cut weights, loin cut tissue percentages and muscle linear measurements among treatment. Gigot width, maximum shoulder width, width behind shoulders, and eye muscle area were greater $(\mathrm{P}<0.05)$ for the Mesquite pods at $200 \mathrm{~g} / \mathrm{kg}$ than the concentrate group with no differences between the concentrate and the Mesquite pods groups with the exception of water holding capacity which was greater in the Mesquite pods at $200 \mathrm{~g} / \mathrm{kg}$ group. Meat of animals of all the treatment groups had similar tenderness score which was within acceptable range. These data indicate that 
feeding fattening Awassi lambs diets containing up to Mesquite pods 200 did not affect carcass and meat characteristics. Nagpal et al. (1995) [3] indicated that 3 months old lambs fed Mesquite pods had higher live weight, hot carcass weight, and dressing percentage than those fed no Mesquite pods. Mahgoub et al. (2005) [4] reported no significant effects upon feeding a concentrate containing Mesquite pods, date palm fruits and by-products on the empty body weight (EBW), carcass weight or dressing out percentage of Omani sheep.

Omani native goats have good potential for meat production, reflected by their high growth rates and good carcass characteristics, when raised under optimum management and nutritional conditions (Mahgoub and Lodge, 1994) [1]. Mahgoub et al. (2005) [4] showed that feeding various levels of Mesquite pods did not cause major effects on body or carcass chemical composition with goats fed $200 \mathrm{~g} / \mathrm{kg}$ Mesquite pods diet having heavier carcasses.

Meat colour is an important parameter influencing consumer purchasing choice, while flavour and tenderness are evaluated during eating. It is well known that animal dietary regime strongly effects meat colour (Priolo et al., 2001) [5], and the fatty acids composition of meat (Wood et al., 2003) [6]. Abdullah and Abddelhafes (2004) [7] found that inclusion of up to $250 \mathrm{~g} / \mathrm{kg}$ of Mesquite pods in lamb diets did not have a negative impact on carcass characteristics. Abdullah et al. (2011) [8] reported that sesame hulls and Mesquite pods can partially replace up to $300 \mathrm{~g} / \mathrm{kg}$ of the soybean and barley in the finishing diets for goats without affecting carcass characteristics, non-carcass components or carcass cuts proportions. Ahmed et al. (2012) [9] reported the potential use of Mesquite pods but not leaves for Ethiopian Afar lambs without adverse effects on growth and carcass characteristics.

Several studies have shown the potential of using low level of Mesquite pods as animal feed but the effects of incorporating high level of soaked or roasted Mesquite pods on carcass and meat quality of Omani sheep thas not been studied. In this way, the novelty of this study is to evaluate the effect of inclusion of soaked or roasted Mesquite pods at $50 \%$ on carcass and meat quality of Omani sheep.

\section{Materials and Methods}

\section{Animals and feeding management}

The Mesquite-pod-based diets were formulated and pelleted from $500 \mathrm{~g} / \mathrm{kg}$ ground Mesquite pods, $240 \mathrm{~g} / \mathrm{kg}$ wheat bran, $200 \mathrm{~g} / \mathrm{kg}$ barley grain, $50 \mathrm{~g} / \mathrm{kg}$ local dried sardines and $10 \mathrm{~g} / \mathrm{kg}$ of salt. Twenty four 10 months-old intact Omani male lambs with average body weight of $27.3 \mathrm{~kg}( \pm 0.5 \mathrm{~kg}$ ) were used in a feeding trial for 84 days. They were divided (on body weight basis) and allocated to four diet combination groups. These were: Rhodes grass hay (RGH) plus a commercial concentrate (CC); RGH plus raw Mesquite pods based concentrate (RMPC); RGH plus roasted Mesquite pods based concentrate (ROMPC); RGH plus soaked Mesquite pods based concentrate (SMPC). Animals were fed the hay ad libitum in individually pens and offered ad daily of $500 \mathrm{~g}$ of the concentrates with free access to water and minerals blocks.

\section{Slaughtering of experimental animals}

At the end of the feeding trial, the animals were slaughtered and processed according to routine slaughterhouse procedures. Feed was withheld overnight with free access to water. The weights of fresh non-carcass organs and the hot carcass were immediately recorded. The non-carcass organs included the head, skin, small and large intestine, lungs and trachea, feet, pancreas, spleen, liver, kidney, heart, bladder and testes. The weight of the gut content was computed as the difference between the full and empty weight of the whole digestive tract. The empty body weight (EBW) was calculated as the difference between the slaughter weight and that of the gut content. The carcasses were weighed (hot carcass weight) then chilled at $4{ }^{\circ} \mathrm{C}$ for $24 \mathrm{~h}$ and reweighed to determine cold carcass weight.

\section{Meat quality assessment}

Samples of Longissimus dorsi (LD) were dissected from both sides of the loin region of each carcass. The following meat quality related measurements were determined.

For the ultimate $\mathrm{pH}$, meat samples (1.5-2 g) were homogenates (using an Ultra Turrax T25 Homogenizer) in $10 \mathrm{ml}$ of distilled water. The ultimate $\mathrm{pH}$ was determined using a Metrohm $\mathrm{pH}$ meter (model no. 744) with a glass electrode. The homogenizer and the $\mathrm{pH}$ meter electrode were washed with distilled water between measurements. The $\mathrm{pH}$ meter was neutralized in a buffer to $\mathrm{pH}$ 7.0 before each measurement.

Shear force value was assessed using a digital Dillon Warner - Bratzler shear device after cooking in a water bath at $70{ }^{\circ} \mathrm{C}$ for 90 min (Purchas, 1972) [10]. This device measures the maximum force required to cut across the muscle fibres (Pearson, 1963) [11]. Chilled muscle samples were sliced to $13 \times 13 \mathrm{~mm}$ cross-section cubes and placed in plastic bags. The meat bags were then cooked in water bath. The cooked meat was sheared perpendicularly to the fibres in 1-2 places after they were cooled overnight at $2-4{ }^{\circ} \mathrm{C}$. The displayed readings were recorded and average values were obtained.

Cooking loss was determined in $13 \times 13 \mathrm{~mm}$ cross-section meat sample cubes. The meat cubes were weighed and placed in polyethylene bags to be cooked in a water bath at $70{ }^{\circ} \mathrm{C}$ for $90 \mathrm{~min}$. The cooked meat then cooled overnight at $2-4{ }^{\circ} \mathrm{C}$ after removing the water produced due to cooking from the bags. The cooked meat samples were reweighed and cooking loss was estimated as the difference between before and after cooking weights. 
Determinations of the water holding capacity (in terms of expressed juice) were based on measuring the loss of water liberated by applying pressure $(10 \mathrm{~kg})$ to the muscle tissue. Expressed juice was assessed using a filter paper method as the total wetted area minus the meat area $\left(\mathrm{cm}^{2}\right)$ relative to the weight of the sample $(\mathrm{g})$ (Hamm, 1986) using a planimeter [12].

Approximately 60 minutes after exposing the fresh surface of LD muscle, CIE $L^{\star}, a^{\star}, b^{\star}$ light reflectance coordinates of the muscle surface were measured at room temperature $\left(20 \pm 2{ }^{\circ} \mathrm{C}\right)$ using a Minolta Chroma Metre CR-300 (Minolta Co., Ltd., Japan), with a colour measuring area $1.1 \mathrm{~cm}$ diameter. The meter was calibrated using a Minolta calibration plate $\left(L^{\star}=97.59, a^{\star}=-5.00, b^{\star}=\right.$ +6.76). The $L^{\star}$ value relates to Lightness; the value to Red-Green hue where a positive value relates to the red intensity; and the $b^{\star}$ value to the Yellow-Blue where a positive value relates to yellow. The average of two measurements from each sample was recorded as the colour coordinate value of the sample.

Sarcomere length was determined by laser diffraction according to the procedures of Cross et al. (1981) [13]. A 5 mm section was removed from the centre of selected muscle and each section was divided into four equal-size pieces with one piece from each section was randomly chosen. Small bundles of fibers were dissected out on a glass slide and covered with a drop of buffered ( 0.05 M Tris, pH 6.6) 0.25M sucrose solution (Stromer et al., 1967) [14].

\section{Statistical analyses}

Analysis of variance procedure (Ott, 1993) [15], was made to evaluate the effect of commercial concentrate, raw, roasted or soaked Prosopis pods based diets on the body weight gain, feed intake, performance, carcass, non-carcass and meat quality parameters using SAS (2001) package [16]. Significant differences between treatments means was assessed using the least-significant difference procedure. Interaction between the treatments were excluded from the model when not significant $(\mathrm{P}>0.05)$.

\section{Results and Discussion}

\section{Body and carcass characteristics}

Table 1 shows body and carcass characteristics of Omani sheep fed on raw or treated Mesquite pods based concentrates. Sheep fed on the CC based diet had higher slaughter, carcass and empty body weight (EBW) than those fed on RMPC or SMPC diets but these parameters were not significantly different $(p>0.05)$ between CC or those from ROMPC group.

\begin{tabular}{|c|c|c|c|c|c|c|c|}
\hline \multirow[b]{2}{*}{ Parameter } & \multicolumn{7}{|c|}{ Diet } \\
\hline & $\mathrm{CC}$ & RMPC & ROMPC & SMPC & SEM & $P>F$ & Sig. \\
\hline Slaughter weight (kg) & $37.96^{\mathrm{a}}$ & $32.94^{\mathrm{b}}$ & $35.48^{\mathrm{a}, \mathrm{b}}$ & $31.44^{\mathrm{b}}$ & 0.80 & 0.01 & $* *$ \\
\hline Empty body weight (kg) & $34.63^{\mathrm{a}}$ & $29.08^{b}$ & $32.35^{\mathrm{a}, \mathrm{b}}$ & $27.85^{\mathrm{b}}$ & 0.78 & 0.00 & $* *$ \\
\hline Hot carcass weight (kg) & 16.40 & 13.12 & 14.99 & 12.50 & 0.63 & 0.00 & $* *$ \\
\hline Cold carcass weight (kg) & 15.09 & 12.17 & 13.84 & 11.53 & 0.58 & 0.00 & $* *$ \\
\hline Shrinkage \% & 7.99 & 7.27 & 7.63 & 7.76 & 0.19 & 0.63 & NS \\
\hline Dressing-out percentage & 43.37 & 39.79 & 42.37 & 39.98 & 0.96 & 0.49 & NS \\
\hline
\end{tabular}

This indicated that sheep fed on diets based on roasted pods may be compromised on their meat production abilities. Mahgoub et al. (2005) [4] reported that goats fed $200 \mathrm{~g} / \mathrm{kg}$ per day of Mesquite pods had higher body weight and hot and cold carcasses with lower shrinkage. Similarly, Nagpal et al. (1995) [3] reported that lambs fed on Mesquite pods had higher live weight and hot carcass weight than those fed without Mesquite pods. Mesquite pods inclusion at levels of 100 to $350 \mathrm{~g} / \mathrm{kg}$ did not cause impact in empty body weight and carcass characteristics (Abdullah and Abdelhafas., 2004; Ali et al., 2012) [7]. Findings in present study showed no differences between treatment groups in terms of hot and cold carcass weight percentages which are supported by Obeidat et al. (2008) [2] who found no negative effects of inclusion of Mesquite pods at levels of 100 and $200 \mathrm{~g} / \mathrm{kg}$ in Awassi lambs finishing diets on hot and cold carcass weights. Mahgoub et al. (2005) [4] reported no negative effects upon feeding a concentrate containing Mesquite pods and date palm fruits and by-products on the empty body weight, carcass weight or dressing out percentage of Omani sheep however, the empty body weights in the current study were significantly different $(\mathrm{p}<0.05)$ mainly due to high body growth rate of CC and ROMPC fed sheep. Therefore, feeding of Mesquite pods to sheep under arid conditions appeared to be a good option. Findings of the current study also indicated that roasting pods was beneficial as it resulted in heavier animals with heavier carcasses. This method may be recommended for local farmers.

The fresh weights of the carcass and body components and non-carcass weights of Omani sheep fed different concentrates are given in Table 2.

In general, there were no significant differences in weights of most body components across experimental groups. The fullalimentary tract however was significantly higher in sheep fed CC and ROMPC compared to the other groups. There was a positive significant effect $(\mathrm{p}<0.05)$ for both commercial concentrate and ROMPC diet on the slaughter body weight and empty body weight, 
this is mainly due to the higher final weights compared to the other groups. However, there were no treatment effects on dressing and shrinkage percentages. The hot carcass and cold carcass weights were not affected ( $p>0.05)$ by type of diets.

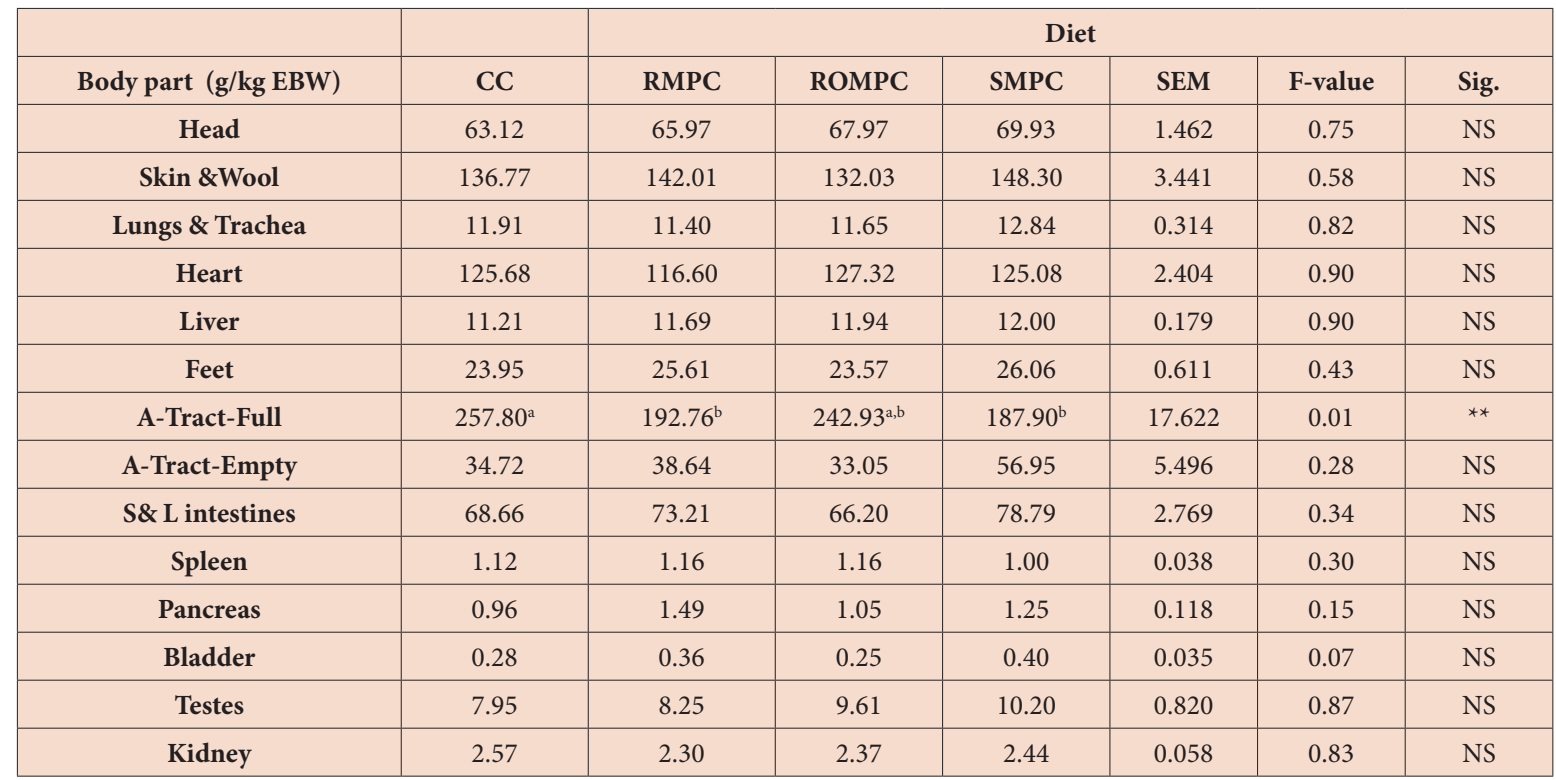

CC: Commercial concentrate ; RMPC: Raw Meskit pods based concentrate; ROMPC: Roasted Meskit pods based concentrate; SMPC: Soaked Meskit pods based concentrate, SEM: standard error of means, $P>F=$ Level of significant, Sig.: Significance

${ }^{* *}$ : $\mathrm{p}<0.01$; NS: Non significant; ${ }^{\mathrm{a}, \mathrm{b},}$ Means on the same row with same sharing superscripted letter do not differ significantly ( $>0.05$ )

Table 2: Mean weights of body parts and carcass components of Omani sheep fed on raw or treated Meskit pods based concentrates

There were no significant effects of feeding Mesquite pods concentrates on body components however, animals fed with CC and ROMPC had higher full alimentary tract. This is most probably due to higher feed intake compared to the other diets groups. It is also probably due to the accumulation of fibre of the ROMPC. Mesquite pods would have longer retention time in the rumen due to its higher fibre content. Ahmed et al. (2012) [9] reported that Mesquite fed sheep increased proportions of edible parts of the carcass. This may be true in absolute terms but not as proportion of EBW. Obeidat et al. (2008) [2] found no negative effects of feeding up to $200 \mathrm{~g} / \mathrm{kg}$ of Mesquite pods on carcass characteristics including gigot width, maximum shoulder width, width behind shoulders, and eye muscle area were greater.

\section{Meat quality evaluation}

The meat $\mathrm{pH}$ for 24 hours after slaughtering of Omani sheep fed raw or treated Mesquite pods are given in Table 3 and 4 . There was no impact of the type of feed in the meat $\mathrm{pH}$ at 24 hours. The highest $\mathrm{pH}$ values were at 40 minutes after slaughtering at ranged between 5.83 for CC to 6.39 for SMPC fed animals. At the end of 24 hours after slaughtering, $\mathrm{pH}$ values were the lowest for all the animals at a different type of feed with a desirable $\mathrm{pH}$ range of 5.52-5.64 and there were no significant differences between treatments. Meat ultimate $\mathrm{pH}$ values in the present study did not differ between the four diet groups and they were within the range for sheep reported by Carson et al. (2001) and Mahgoub et al. (2005) [4,17]. However, these values were higher than those reported by Devine et al. (1993) and Lanza et al. (2003) [18,19] for ultimate $\mathrm{pH}$ values. The ultimate $\mathrm{pH}$ value relies on the level of glycogen at slaughter. Therefore, lack of differences in ultimate $\mathrm{pH}$ values between the four diet groups indicates that there was no effect of the diet, on the muscle glycogen content at slaughter.

\begin{tabular}{|c|c|c|c|c|c|c|c|}
\hline \multirow[b]{2}{*}{ Test type } & \multirow[b]{2}{*}{$\mathrm{CC}$} & \multicolumn{6}{|c|}{ Diet } \\
\hline & & RMPC & ROMPC & SMPC & SEM & $P>F$ & Sig. \\
\hline Ultimate $\mathrm{pH}$ & 5.64 & 5.50 & 5.52 & 5.57 & 0.05 & 0.81 & NS \\
\hline \multicolumn{8}{|l|}{ Colour } \\
\hline$L^{\star}$ (Lightness) & 32.29 & 30.75 & 31.75 & 32.70 & 0.55 & 0.65 & NS \\
\hline$a^{\star}$ (Redness) & 12.89 & 13.22 & 15.57 & 11.91 & 0.56 & 0.12 & NS \\
\hline$b^{\star}$ (Yellowness) & 3.43 & 3.57 & 4.67 & 3.58 & 0.25 & 0.18 & NS \\
\hline Cooking loose $(\mathrm{CL}) \%$ & 12.32 & 13.56 & 13.99 & 13.14 & 0.47 & 0.67 & NS \\
\hline Shear force $(\mathrm{kg})$ & 4.06 & 3.76 & 3.78 & 4.02 & 0.10 & 0.67 & NS \\
\hline Express juice $\left(\mathrm{cm}^{3} / \mathrm{g}\right)$ & $31.81^{\mathrm{a}}$ & $34.66^{\mathrm{a}, \mathrm{b}}$ & $37.96^{\mathrm{b}}$ & $32.85^{\mathrm{a}, \mathrm{b}}$ & 0.87 & 0.05 & * \\
\hline Sarcomere length $(\mu \mathrm{m})$ & 1.82 & 1.86 & 1.83 & 1.81 & 0.02 & 0.89 & NS \\
\hline
\end{tabular}

CC: Commercial concentrate ; RMPC: Raw Meskit pods based concentrate; ROMPC: Roasted Meskit pods based concentrate; SMPC: Soaked Meskit pods based concentrate, SEM: standard error of means, $P>F=$ Level of significant, Sig.: Significance ${ }^{*}$ : $\mathrm{p}<0.05$; NS: Non significant; ${ }^{\mathrm{a}, \mathrm{b}}$, Means on the same row with same superscripted letter do not differ significantly ( $\mathrm{p}>0.05$ ) Table 3: Meat quality parameters of Omani sheep fed on raw or treated Meskit pods based concentrates 


\begin{tabular}{|c|c|c|c|c|c|c|c|}
\hline & & \multicolumn{5}{|c|}{ Diet } \\
\hline Parameter & CC & RMPC & ROMPC & SMPC & SEM & F-value & Sig. \\
\hline 40 Minutes & 5.83 & 5.95 & 6.09 & 6.39 & 0.13 & 0.49 & NS \\
\hline Two hours & 6.05 & 6.07 & 5.94 & 5.81 & 0.06 & 0.48 & NS \\
\hline Four hours & 6.07 & 5.87 & 5.91 & 5.94 & 0.05 & 0.44 & NS \\
\hline Eight hours & 5.77 & 5.58 & 5.70 & 5.70 & 0.05 & 0.68 & NS \\
\hline Twelve hours & 5.68 & 5.53 & 5.61 & 5.62 & 0.05 & 0.75 & NS \\
\hline Twenty-four hours & 5.64 & 5.50 & 5.52 & 5.57 & 0.05 & 0.81 & NS \\
\hline
\end{tabular}

CC: Commercial concentrate ; RMPC: Raw Meskit pods based concentrate; ROMPC: Roasted Meskit pods based concentrate; SMPC: Soaked Meskit pods based concentrate, SEM: standard error of means, P>F = Level of significant, Sig.: Significance. NS: Non significant Table 4: Measurements of muscle pH for 24 hours after slaughtering of Omani sheep fed on raw or treated Meskit pods based concentrates

There were no significant effects ( $\mathrm{p}>0.05$ ) of feeding Mesquite pods based diets on sheep meat quality parameters including ultimate $\mathrm{pH}$, colour, cooking loss, shear force or sarcomere length (Table 3). The only effect was in expressed juice with ROMPC sheep having high values. There were no differences in brightness $\left(L^{*}\right)$, redness $\left(a^{*}\right)$, yellowness and hue angle between all treatment diets. Shear force was not affected by the experimental diets and it was below $6 \mathrm{~kg} / \mathrm{cm}^{3}$. Obeidat et al. (2008) [2] reported that meat quality parameters were comparable among the treatment diets with the exception of water holding capacity which was greater in the sheep fed $200 \mathrm{~g} / \mathrm{kg}$ Mesquite pods and Pena-Avelino et al. (2017) [20] reported that lambs fed Mesquite pods decreased shrinkage percentage. In the current study, meat of animals of all the treatment groups had similar tenderness score which was within acceptable range.

Least square means of LD muscle quality are shown in Table 3. No differences were noticed within treatment diets in cooking loss and shear force values. However, water holding capacity was higher for ROMPC group than the other and meat ultimate $\mathrm{pH}$ values did not differ amongst diet groups.

Water holding capacity measured as expressed juice were higher for animals fed ROMPC compared to CC group but similar than other Mesquite pods groups. Meat colour is an important parameter influencing consumer purchasing choice. It is known that animal dietary regimen strongly effects meat colour (Priolo et al., 2001) [5]. However, there were no differences in brightness $\left(L^{\star}\right)$, redness $\left(a^{*}\right)$, yellowness $\left(b^{*}\right)$, and hue angle between all treatment diets. Colour measurement values of LD muscle were comparable among the four groups and were similar of finding of Mahgoub et al. (2005) [4] for Omani sheep fed diets containing Mesquite pods.

Meat quality parameters measured were comparable among all the treatment diets except for the water holding capacity that resulted more favourable in CC compared to other groups. Water holding capacity was better in lambs fed commercial concentrate. Sarcomere length and Warner-Bratzler shear force were not affected by the experimental diets, and it was below $6 \mathrm{~kg} / \mathrm{cm}^{2}$.

The $\mathrm{pH}$ values for all treatments were within the acceptable range at which meat is considered to be tender (Qudsieh, 2006) [21]. Shear force values amongst the groups were within the normal range as well. Field et al. (1971) reported that tenderness values around $3.6 \mathrm{~kg} / \mathrm{cm}^{2}$, or less is grouped to have likeable tenderness for sheep and goats meat. These findings were similar with the values stated by Qudsieh (2006) for sheep meat measured at various slaughtered weights [21]. Shear force was not affected by the experimental diets and it was below $6 \mathrm{~kg} / \mathrm{cm}^{2}$, which accounted for acceptable tender samples [17-19] studying the effects of different diets on meat quality of sheep, found no effect on sarcomere length or WB-shear force and Shamseldein et al. (2013) [22] cited that addition of Mesquite pods up to $30 \%$ in the diet showed no adverse effect to growing goats.

The meat $\mathrm{pH}$ for 24 hours after slaughtering of Omani sheep fed raw or treated Mesquite pods are given in Table 4. In the current study, there was no impact of the type of feed in the meat $\mathrm{pH}$ at 24 hours. The highest $\mathrm{pH}$ values were at 40 minutes after slaughtering at ranged between 5.83 for CC fed animal to 6.39 for SMPC fed animals and then started to decline by the process of glycolysis which is the conversion of glycogen to lactic acid. At the end of $24 \mathrm{~h}$ after slaughtering, $\mathrm{pH}$ values were the lowest for all the animals at different type of feed with a desirable $\mathrm{pH}$ range of 5.52-5.64 and there were no significant differences between treatments. Meat $\mathrm{pH}$ has a desirable range of 5.4-5.8 and meat with a pH between 5.8 and 6.0 is known to be intermediate, while meat with a pH greater than 6.0 considered high. The $\mathrm{pH}$ influences meat quality in a number of ways; a high $\mathrm{pH}>6.0$ can permit the growth of spoilage bacteria which decrease shelf-life; intermediate $\mathrm{pH}$ increases meat toughness, while low pH meat can be "mushy"; high pH meat is darker (has a lower $\mathrm{L}^{\star}$ brightness score) and is often referred to as "dark-cutting meat".

\section{Conclusion}

This study aimed at processing Mesquite pods and incorporating them in sheep diets to study their effect on carcass characteristics and meat quality of Omani sheep. The study demonstrated the potential of using Mesquite pods at level of $50 \%$ in diets of growing lambs without causing negative effects on carcass and meat quality of Omani sheep. 


\section{References}

1. Mahgoub O, Lodge GA (1994) Growth and body composition of Omani local sheep 1. Live-weight growth and carcass and non-carcass characteristics. J Ani Prod 58: 365-72.

2. Obeidat BS, Abdullah AY, AL-Lataifeh FA (2008) The effect of partial replacement of barley grains by Prosopis juliflora pods on growth performance, nutrient intake, digestibility, and carcass characteristics of Awassi lambs fed finishing diets. Anim Feed Sci Technol 146: 42-54.

3. Nagpal AK, Singh D, Prasad VS, Jain PC (1995) Effects of weaning age and feeding systems on growth performance and carcass traits of male kids in three breeds in India. Small Rumin Res 17: 45-50.

4. Mahgoub O, Kadim IT, Forsberg NE, Al-Ajmi DS, Al-Saqry NM, et al. (2005) Evaluation of Mesquite (Prosopis juliflora) pods as a feed goats. Anim Feed Sci Technol 121: 319-27.

5. Priolo AI, Micol DE, Agabriel JH (2001) Effects of grass feeding systems on ruminant meat colour and flavour. A review Anim Res 50: 185-200.

6. Wood JD, Richardson RI, Nute GR, Fisher AV, Campo MM, et al. (2003) Effects of fatty acids on meat quality: a review. Meat Sci 66: 21-32.

7. Abdullah AY, Abddelhafes BY (2004) Inclusion of Prosopis juliflora pods in finishing Awassi lambs diets. In: Proc. 11th AAAP Animal Sciences Congress 2: 373-5.

8. Abdullah YA, Bela SO, Marwan MM, Sulaiman KM, Majdi AA (2011) Growth performance, carcass and meat characteristics of black goat kids fed sesame hulls and Prosopis juliflora Pods. Asian-Aus J Anim Sci 24: 1217-26.

9. Ahmed SA, Sayan T, Sarawut R, Kriengki K (2012) Effect of feeding prosopis juliflora pods and leaves on performance and carcass characteristics of Afar sheep. Kasetart J Nat Sci 46: 871-81.

10. Purchas R (1972) The relative importance of some determinants of beef tenderness. J Food Sci 37: 341-5.

11. Pearson AM (1963) Objective and subjective measurements for meat tenderness. In Proceedings Meat Tenderness Symposium 135-58. New Jersey: Campbell Soup Co, USA.

12. Hamm R (1986) Functional properties of the myofibrillar system and their measurements. Ch. 4 in Muscle as Food, P.J. Bechtel (Ed) Acadmic Press, Inc., Orlando, FL, USA.

13. Cross HR, West RL, Dutson TR (1981) Comparison of methods for measuring sarcomere length in beef semitendinosus muscle. Meat Sci 5: 261-6.

14. Stomer MH, Goll DE, Roth LE (1967) Morphology of rigor-shortened bovine muscle and the effect of trypsin on pre-and postrigor myofibrils. J Cell Bio 34: $431-45$.

15. Ott RL (1993) Analysis of variance in some standard experimental designs In: Introduction to Statistical Methods and Data Analysis, Duxbury Press, Belmont, CA, USA.

16. SAS (2001) SAS User’s Guide: Statistics (version 9), Cary, NC: SAS Institut Inc., USA.

17. Carson AF, Moss BW, Dawson ER, Kilpatrick DJ (2001) Effects of genotype and dietary forage to concentrate ratio during the finishing period on carcass characteristics and meat quality of lambs from hill sheep systems. J Agric Sci Camb 137: 205-20.

18. Devine CE, Graafhuis AE, Muir PD, Chrystall BB (1993) The effect of growth rate and ultimate pH on meat quality of lambs. Meat Sci 35: 63-77.

19. Lanza M, Bella M, Barbagallo D, Fasone V, Finocchiaro L, et al. (2003) Effect of partially or totally replacing soybean meal and maize by chickpeas (Cicer arietinum L.) in lambs diets: growth performance, carcass and meat quality. Ani Res 52: 263-70.

20. Peña-Avelino L, Pinos-Rodríguez J, Vicente J, García-López J, Yáñez, L, et al. (2017) Effects of Prosopis laevigata pods on carcass characteristics, non-carcass components, meat quality, fatty acid profile and sensory attributes. South African J Anim Sci 47: 785.

21. Qudsieh RI (2006) The effect of body weight on meat quality of Awassi ram lambs. Thesis, Jordan University of Science and Technology, Irbid, Jordan.

22. Shamseldein H, Ahmed A, Omer M, Ali S, Sakata T, et al. (2013) Effect of Feeding Rations Containing Different Levels of Mesquite Pods on growth and Carcass Characteristics of Sudanese Nubian Goats. Eur Int J Sci Technol 9: 237-44.

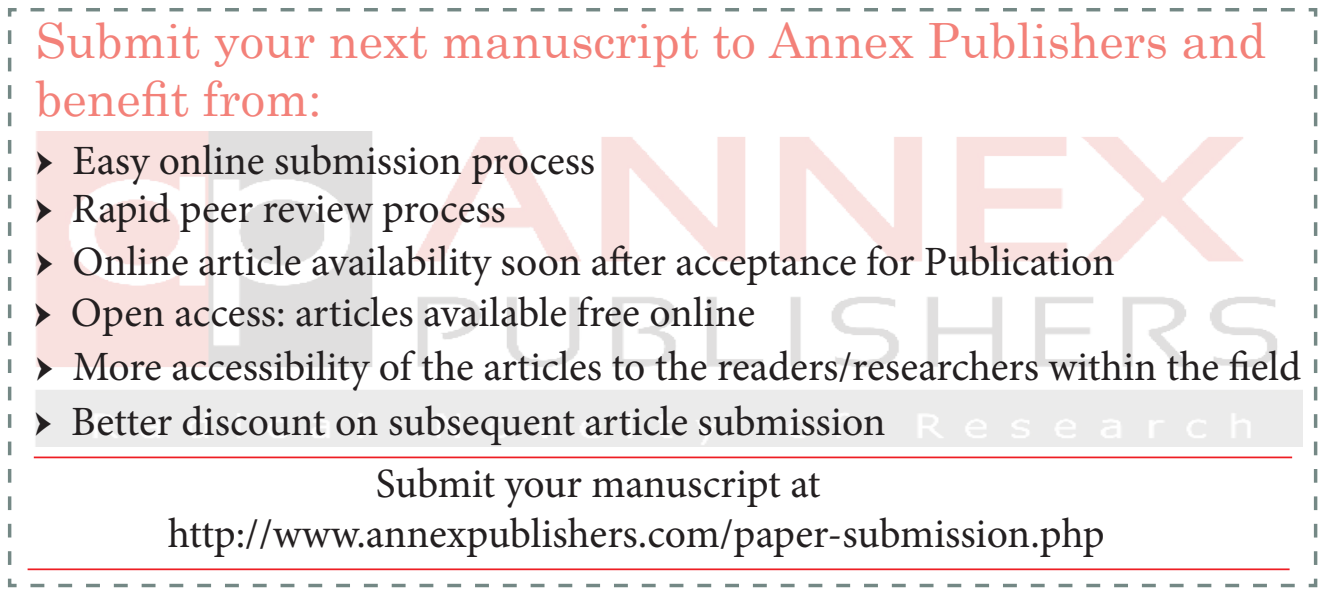

